\title{
Teaching gender within International Relations: \\ Experiences from a Brazilian University Classroom
}

\section{By VÂnia Carvalho Pinto}

\begin{abstract}
In this article I propose to reflect upon my classroom experiences and didactical practices teaching gender and international relations (IR) at the University of Brasilia. The empirical examples will be drawn from two undergraduate courses: theory of international relations and international relations of the Middle East. The main issue that I am addressing in this article is the students' resistance to the study of gender within IR. Part of the problem rests within the structure of the mainstream discipline as the latter tends to over focus on the systemic level of analysis, a theoretical abstraction that renders women (and people in general) invisible. Given that IR students typically become our future diplomats and civil servants, training in foreign policy must not be allowed to rest on depersonalised state relations, which will at best deliver unidirectional and simplistic views of the world. To that end, I propose a set of topics, literature and pedagogical practices of how to mainstream gender into a general IR discipline. The main points underlying this proposal are to emotionally engage students by carefully selecting which IR topics to study and to decrease the level of abstraction by utilizing real-life up-to-date case studies and examples.
\end{abstract}

\section{KEYWORDS}

feminism, gender, emotion, teaching, international relations/

feminisme, køn, følelser, undervisning, internationalt samarbejde

VÂnia Carvalho Pinto is assistant Professor. Institute of International Relations, University of Brasília, Brazil. Her research interests include: International relations of the Persian Gulf, with a focus on the UAE; feminism and foreign policy and comparative area studies focusing on Gulf Arab countries, Latin America and Scandinavia. 


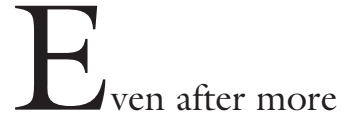

than twenty years of feminist IR knowledge production, gender still has difficulties being recognised as relevant for the study of international politics within mainstream IR (see, e.g., Sylvester, 2013; Tickner, 2005). An absence that is identified as an enduring silence within the discipline (Dingli 2015: 1-22). The existence as well as the persistence of this state of affairs can be traced to a dialogical relationship between (i) the published discipline; (ii) the instructed discipline; 1 and, I would add, (iii) the learnt discipline. The marginal position that feminism still occupies within mainstream published IR gives rise to a dearth of teaching materials with which to show IR from a gendered standpoint (Sjoberg 2006: 338; Oestreich 2007: 328). Even if today there are some resources that offer a very didactical gendered perspective (e.g. Steans 2011; Shepherd 2010), available materials are still limited both in terms of quantity as well as in the range of perspectives offered. ${ }^{2}$ In the same vein, gender is also seldom taught within IR classrooms, as a recent survey of the curricula of top universities across the US and Europe has shown (Hagmman and Biersteker 2014: 299, 304). This being the situation in the 'global north', moving towards the geographical (and epistemological) south, we can find some differences as regards the picture painted above. If marginality characterises the general state of the published discipline, Brazil offers a slightly different picture. A very cursory examination of the published articles in the last few years within the main Brazilian IR journals $^{3}$ shows that absence rather than marginality characterises the state of published feminist IR in this part of the world. ${ }^{4}$ A survey of Latin American and Caribbean university IR curricula conducted by Arlene Tickner (2009: 42) encountered similar results. She found that feminism was largely ignored in over one third of all syllabuses examined and given only passing attention in all the others.

How can we account for such a state of affairs? I offer three sets of explanations, each located within one of the factors identified before. As regards the published/research nexus, the structure of the mainstream discipline itself still favours the presumably more 'scientific' systemic level of analysis - to the detriment of the often more relevant state and individual levels where 'people', not just women, are invisible. 5 Second, within the taught discipline, the lecturer's own struggles for peer (and student) recognition are also important. Considering that IR is a discipline that tends to be resistant to these topics, maybe the former helps explaining the relative absence of gender within the various syllabuses. I experienced these dilemmas first-hand the first time I taught the undergraduate course of International Relations of the Middle East (IRME). Deciding which gender topics to include and how amidst so many other themes that students perceived as so much more relevant nowadays (such as the Arab Spring and terrorism, just to name a few), led me to articulate specific gender issues with carefully chosen topics of international politics. Furthermore and adding to this dilemma, it was my second semester teaching at the University of Brasília and at the time I was keen to show my 'IR credentials' ${ }^{6}$

Third, the students claim that gender and IR are not connected. Reactions of hostility and defensiveness to the inclusion of gender topics in the IR syllabus seem to characterise students' attitudes in several parts of the world. Laura Sjoberg (2007: 337 ), writing about her experiences in the US, suggests that such a reaction occurs because gender personalizes IR and forces students to acknowledge that decisions taken in the international realm do affect the lives of people on the ground. That may 
well be so. However, in my particular experience, I felt that in some situations the students just did not want to study gender. Indeed, I think that in the vast majority of cases the problem was that they did not consider the study of gender to bear any relevance for the study of international relations. This is a perception that needs addressing. Indeed, if IR continues to be taught around the world by the guise of a universal viewpoint and focused on a systemic level of analysis, we are training our future diplomats and civil servants to be utterly oblivious to people's lives. ${ }^{7}$ As lecturers we do hold the responsibility of having chosen to advance some worldviews in the classroom instead of others (see Hagmman \& Biersteker 2014: 297-298), having therefore impacted what our students absorb as being the 'stuff' of international politics.

In what follows, I reflect upon my experiences teaching gender and IR at the University of Brazilia and suggest topics, literature and strategies that have helped me mainstream gender. Related to this, I propose a brief guide on how to introduce feminism into IR in a manner that promotes reflexivity by utilizing up-to-date real-life international politics examples that can foster identification with the 'people' within IR. In practical terms, such an approach would entail choosing materials and dealing with them in such a way that the topics could resonate with students in a personal sense. Part of this strategy would involve utilizing some elements of active learning (through the use of case studies and visual aids), combined with feminist methods centred on reflexivity and empowerment. Within this general framework, two challenges need addressing: first, simplifying while simultaneously fleshing out very abstract concepts; and second, presenting feminist research - in all its diversity and complexity - in a pedagogical way. Since much of the abstraction derives from the fact that the discipline draws on very specific experiences, from the US and the West in general, utilizing examples from different parts of the world in order to illustrate theory is a great advantage.

\section{ADDRESSING THE 'INNER TURMOIL': LEARNING GENDER IS PERSONAL}

As previously mentioned, learning gender is not a neutral experience for students. Throughout the years, my classroom has tended to become increasingly sympathetic to gender issues - mainly because students either decide to enrol in it or not. As a result, I often forget how unnatural the topic seems to IR students. The occasional antagonistic reaction is a good reminder in that regard. In a 2014 IRME class, a female student that had previously attended my lectures was annoyed that this subject had made its way into a Middle East course, and she claimed in class that gender issues did not belong to IR. Her reaction was not about studying gender within Middle Eastern studies, but rather to study gender within IR (in this case of the middle east, but it could be of any other region). More recently, in May 2015, I was invited to deliver a guest lecture on feminism and IR at an introductory second semester undergraduate class. The blank expressions and bored gazes that 'welcomed' my lecture as soon as I mentioned the word feminism reminded me again of the sorry state the learnt discipline currently finds itself in.

These kinds of reactions make it even more pressing to devise a pedagogical strategy that can 'entice' the student audience. This would entail particular effort from the lecturer, as he/she must steel oneself to go beyond initial (collective) dismissive reactions and strive to show the relevance of gender issues for the workings of international politics. I suggest that a meaningful intertwining of gender and international politics requires that emotion 8 explicitly underlie the teaching and learning dynamic. The students' intense reaction that comes 
about from studying gender and IR can be channelled into a teaching and learning approach based on Christine Sylvester's method of empathetic cooperation. This method refers to

"a process of positional slippage that occurs when one listens seriously to the concerns, fears, and agendas of those one is accustomed to heeding when building social theory, (...) [thus] finding in the concerns of others borderlands of one's own concerns and fears" (Sylvester 1994: 317).

Since gender subordination is universal but manifests itself differently around the world, hearing and speaking about each other's lives and the emotional identification that accompanies these conversations can produce common ground to understand gender subordination (Sjoberg 2006: 48 ). This approach thus consists in generating identification with the Other so as to foster a learning environment characterized by reflexivity and by personal engagement with difference (see Shrewsbury 1993). The application of a relational pedagogy is particularly important as talking about gender generates a sort of inner 'tumult' due to its unsettling of categories associated to 'class, race, ability, and economic and geographic location'. If left unproblematized, it may generate those kinds of 'certainties' that certain things only occur 'out there' with 'those people' 9 , thus leading to an exoticized view of the matter at hand. This is true. However, the extent to which studying gender also unsettles categories associated with one's life experiences tends to be less problematized. Within feminist literature, this tends to be addressed under the guise of empowerment and reflexivity, although the ways it actually occurs - how that feeling can be induced and what kinds of reactions students will have - is less tackled.

The experiences in my classroom can be quite illustrative in this regard. As previous- ly mentioned, Brazilian students similarly to other IR undergraduates around the world display an intense reaction to the introduction of gender studies into the syllabus. If the majority is displeased, some of the students become quite enthralled with the idea. My sense of the matter is that these particular students feel that finally they were studying a topic that has some relevance for their daily lives. This belief, from what I understood, flows from their need to address issues of gender and feminism in a more structured way than what is usually offered in their studies. They were thus keen to discuss gender issues in general, not necessarily in IR. I offer a very telling example in this regard: the bachelor degree of international relations at the University of Brasília is generally seen as an elite course, which will serve as a precursor to joining the Foreign Service. Hence, it usually attracts students from across the country who wish to become diplomats. Many tend to change their minds throughout the course, but in the first semesters, usually the vast majority of the classroom declares that to be their goal.

In my theory of international relations course (TIR), I use Jacqui True's Feminism (2005), a small piece that addresses the invisibility of women in theories of international society. In it, she examines the hidden and often undervalued (private life) contribution of the wives of diplomats to their country's foreign policy. This is a topic, I then realised, which generates a substantial impression in the female students. Every semester I ask my TIR class who wants to become a diplomat, and I was startled with the reasons that many female students offered as being the primary obstacles to the pursuance of a career in that field. They feared that such a job would hinder their chances of having a family, or more specifically, of being able to stay married, as few men, in their perception, would follow them abroad. I found it astonishing (and depressing) that young women barely 
in their twenties would already consider sabotaging themselves academically (and professionally) in the name of an abstract idea of a family that may well never exist. For me, this became an important dimension of my teaching of IR: to make gender a specific part of it and to include debates on emancipation and various types of femininities and masculinities in such a way that could help them think about their own lives. This experience has led me to believe that our teaching of gender and IR does bear meaningful emancipatory potential.

In general courses such as the ones that I teach - where many other topics are expected to be covered - it is very difficult to escape the tendency of building into the syllabus a gender 'week' or 'fortnight'. This is an approach that may generate the problematic assumption among students that gender is somehow unconnected to and plays no part in international politics (Oestreich 2007: 328). Even if teaching IR from a gendered perspective would be more interesting, it can bring about other difficulties connected for example to departmental politics. My suggestion for those of us that must teach a more general course is to mainstream gender enough throughout the syllabus so as to avoid the perception that gender holds a separate, somehow self-contained existence.

In the following paragraphs, I detail my suggestions for doing so. The choice of topics and literature reflects the 'merciless' politics of location that underlie the activity of teaching far away from the geographical as well as the epistemological centres of knowledge production. Access to specialized bibliography is not easy. International books are expensive and usually not physically available, either in libraries or in bookstores. When ordered from abroad through Amazon or a national bookstore service, they tend to take several months to arrive. In what concerns journal articles, we are fortunate to benefit from Periódicos Capes, an online platform paid for by the Govern- ment that gives access to a wide range of articles in international journals. Regrettably, in many cases, access is deferred for a year, a year and half. This imposes considerable challenges in terms of the up-to-datedness and availability of materials, not only for teaching but also for research. My choice of topics and related literature is thus limited by these circumstances, as I have to utilize whatever is easily accessible to me. In the sections that follow, I suggest a brief practical guide to teaching gender within general IR courses. My proposal specifically focuses on utilizing up to date specific international politics examples as a means to reduce abstraction and if possible drawn from the non-Western world; and on emotion so as to promote reflexivity and identification with the Other. Throughout the years, I have found that the combination of topics and literature that I am presenting next have helped maximize interest among students.

\section{THE PROPOSAL: A BRIEF GENERAL GUIDE FOR FEMINIST IR}

In my TIR course, I introduce gender fairly early within the context of a class on both the Old and the Global Standards of Civilization. These topics are an excellent entry point to start talking about gender within IR as they open space for discussions centred on two relevant issues: the historical subordination of women, and the intertwining of current international events and gender.

The Old Standard of Civilization (OSC) refers to the nineteenth century practices that were generally accepted by 'civilized' European countries and which took an increasingly global and explicitly juridical character as that international system developed. This standard provided a purportedly legal way both to demarcate the boundaries of "civilized" society and to differentiate among "civilized", "barbarous", and "savage" countries internationally. It included 
five requirements, ${ }^{10}$ the fifth being a more subjective element, which is where the status of women enters. A 'civilized' state conformed to the accepted norms and practices of the "civilized" international society; for example, sati (widow suicide burning), polygamy, and slavery were considered "uncivilized" and therefore unacceptable (Gong 2005: 78-80). Therefore, the inexistence of certain practices, which specifically affected women were considered markers of the advancement (or lack thereof) of a society. To discuss these issues in class, I find Ann Town's The Status of Women and the Ordering of Human Societies along the Stages of Civilization (2007) particularly useful. It not only directly connects women's issues with IR, but it also introduces students to $19^{\text {th }}$ century interpretations of the place of women, information they are seldom acquainted with. I found that even the self-declared non-feminists find those opinions on women so revolting that their attention is captured. I complement this class with a small introduction to orientalism from the perspective of the images created about Arab women by European men. I show them pictures from Malek Alloula's The Colonial Harem (1986), a compilation of French postcards of Algerian women produced in the first half of the twentieth century. They portray women with veils or even burkas, usually with their breast exposed, which gives me the entry point to connect with background information on the importance ascribed to the status of women as a means to morally justify colonization (see, e.g., Abu-Lughod 2001). At this juncture I also introduce some ideas from Kwame Anthony Appiah's The Honour Code (2010). Although not being an IR book, it shows how, within the context of European encroachment, Chinese practices such as female foot binding started to be challenged because these, it was argued, not only generated 'weak offspring' - and consequently a weak nation - but the practice also damaged China's international reputation (Appiah 2010: 60). These are not specifically IR materials but they connect themselves well with it. Furthermore, they call students' attention to gender specific violence around the world and clearly show how the situation of women is bound with the states' foreign policy.

I then move into more contemporary affairs; from the dismissal of the old standard of civilization, I address the Global Standard of Civilization (GSC) we are now living under. A globalized era characterised by the convergence of world visions that translate themselves into groups of norms all states proclaim they adhere to. Thus, even if states declare their abidance to them, they constantly reinterpret their meaning so as to adjust them to their own interests. These norms include defending human rights (especially women and minorities), protecting the environment, fighting against terrorism, being a humanitarian, among others (Mozaffari 2001: 251). This general framework is very suitable to the discussion of current events such as the European refugee crisis, the division between north and south of Europe triggered by the Euro bailouts, as well as the gendered aspect of the military interventions in Iraq and Afghanistan, to name just a few. This topic also brings an added bonus: it allows students the chance to take notice of the wide utilization of the terms 'civilization' and 'civilized' in diplomatic discourse as a means to legitimize certain practices. For example, within the context of domestic opposition to Brazilian President Dilma Rousseff's economic policies, I show them an article where she declares to an investor meeting in New York that "Brazil is civilized and respects contracts" (O Globo 2013). Similarly, the above terms were part of Vladimir Putin's discourses justifying the annexation of Crimea. He claimed:

"Everything in Crimea speaks of our shared history and pride. This is (...) where Prince Vladimir was baptized in [988 AD], (...) 
[which] predetermined the overall basis of the culture, civilization and human values of all Russians" (Time 2014).

In my experience, students tend to genuinely enjoy these debates on the standards of civilization because these themes possess a very low level of abstraction and they can connect the syllabus with widely known international events that even the least informed student will be aware of. The importance of bringing current events to the classroom should not be underestimated as what tends to capture student interest is precisely the ability they acquire in class to explain what they see in the news, which is often discussed at home and with their peers. The taught discipline is still quite behind in that regard, as Jonas Hagmman and Thomas Biersteker's (2014: 305) survey of syllabuses in Europe and the US revealed. These display a strong tendency to assign works from the Cold War, usually from around the 1980s.

The discussions above about the standards of civilization offer the background for what Joel Oestreich calls 'the gender week', although in my case it is more of a fortnight. I introduce the characteristics of feminist research with J. Ann Tickner's What is your research program? (2005), which is a text that offers a good context to discuss the particularities of feminist research on the ground. Even though I do subscribe to the idea that the lecturer's experiences may serve as a departure point to further knowledge acquisition and retention, I readily admit my hesitation in sharing personal information in the classroom. ${ }^{11}$ Nevertheless, it is unmistakable that students much better apprehend complicated concepts such as reflexivity and power relations in research (and ultimately in how knowledge is constructed), when I give concrete examples of my own work. Using my own experience as resource, I present the difficulties of researching in authoritarian contexts - such as the ethical dilemmas in dealing with information acquired through interviews; as well as the gender specific hurdles I have experienced as a female researcher within an extremely conservative Arab-Muslim context. These latter issues are seldom examined in the literature, including dealing with harassment as a researcher. Discussing such matters serves a double purpose: students become acquainted with situations 'on the ground' that influence the production (and publication) of knowledge; and sharing these experiences with female (and male) students in an open discursive environment undoubtedly contributes to their own lifelong empowerment both as individuals as well as professionals (see Webb et al. 2004: 420; Shrewsbury 1993; Lee 1993: 27).

Small practical exercises in class targeted to applying the specific topics of the syllabus to news articles are very useful. In order to teach securitization theory, ${ }^{12}$ currently one of the most fashionable topics in IR, I conduct a small exercise based on a 2011 article published in the English online newspaper Daily Mail, entitled The women who have to sleep with their husbands' brothers: Shortage of girls forces families into wife-sharing (Daily Mail 2011). Divided into groups of two for about fifteen minutes, the students must read the article and apply the structure of securitization theory. They conclude that it fails to account for lifethreatening situations where the subject cannot speak and the overall cultural context rejects the validity of the former's claims, in this case the women's. It is a very poignant piece that addresses the issue of gender violence in other parts of the world while illustrating real-life applications of IR theory.

The course of IRME also poses particular challenges. Since this part of the world has been consistently in the news for the past 15 years, students tend to be very keen on expanding their knowledge further about this region. Consequently, they develop high expectations as regards the topics of 
the discipline. This generates two specific challenges: one is the usual resi-stance to the study of gender, although one can explore their curiosity about the topic to steer them into certain study paths. The second, and this is more challenging, is that students develop ideas about the topics they consider should be studied - currently the expansion of the Islamic State; three years ago the Arab Spring. For this reason, I try to use 'established' IR topics to mainstream gender and they have resonated well with students. I suggest three in this regard. The first is the 1979 Iranian Islamic revolution; the second is the states' international projections as women-friendly countries; the third is postcolonialism and the veil.

As regards the first topic, the Iranian Islamic revolution, there are a wide variety of texts that can be used for this purpose. I myself utilize Ziba Mir Hosseini's The Conservative-Reformist Conflict Over Women's Rights in Iran (2002), which illustrates how gender is important in the desired political configuration of a country and its international relations. ${ }^{13}$ The second topic, states as self-projected women-friendly countries, is a theoretical offshoot of the GSC. The latter is a salient current concern of many Arab countries, in particular of the monarchies from the Arabian Peninsula. I focus on the United Arab Emirates (UAE), an Arab country which espouses a very visible policy in that regard. Indeed, the country garnered much attention recently with all the publicity surrounding its first female fighter pilot, Major Mariam al-Mansouri who has been participating in the military attacks on ISIS. Utilizing this very popular news bit gives an entrance point to discussing the importance countries attach to the display of a women-friendly international image. UAE Ambassador Yousef alOtaiba's 2010 interview to the Aspen Ideas Festival is quite a useful resource. It covers a myriad of relevant issues in an extremely candid way, including the country's relationship with Iran and Israel.
The third topic, postcolonialism and the veil, is a topic that can also be connected with IR and it has the advantage of exploring students' curiosity about what often is the one piece of information they have about Muslim women - that they may wear a veil. This issue is easily connected with the debate and literature on the standards of civilization that I detailed earlier thus offering an important entry point into the study of the interrelation between domestic and international politics. In addition to texts, I also tend to extensively use visual aids and documentaries for my classes. Not only do they help bring down the level of abstraction and foster a more relational experience with the subject at hand, ${ }^{14}$ but they also aid in comprehension as well as in the retention of knowledge (Inoue/Krain 2014: 424). The documentary Because our cause is just (2013) that features Arab women protesting for liberal civil rights is a case in point. For students, this helps in countering widespread ideas of Arab women's lack of agency. The usual effect, especially among female students, is of identification with the young women protesting as they can see replicated the same kind of issues (of social justice, no sexual harassment, equal rights), although in different forms, that affect their own lives. The second are the Emirati cartoons Freej. ${ }^{15}$ To my knowledge, one needs to travel to the Arabian Peninsula to get them, so they are not easy to obtain. Nevertheless, they have been a useful teaching resource that has been quite successful in both undergraduate and graduate courses. The cartoons are extremely entertaining, spoken in Arabic with English subtitles. Focused on the 'adventures' of four grandmothers, they deal with several aspects of Emirati (Gulf Arab) society in an informative and humorous way. They help students visualize what life would be like in that part of the world, thus aiding both in the 'demystification' of Arab culture as well as in seeing Arab women as empowered agents. 


\section{CONCLUDING REMARKS}

The discipline of IR, as a published, taught and learnt discipline, continues to have difficulties embracing feminist critique and engagement. If absence rather than marginality characterises the state of the published discipline in Brazil, the country simultaneously shares the same limitations found in other regions of the globe as regards the two other levels of teaching and learning. The structure of the mainstream discipline, the students' resistance to the study of gender, as well as the paucity of pedagogical IR materials addressing feminist perspectives, are all interrelated matters that contribute to this state of affairs. Having dealt with these issues, with the added limitation of having difficulties to access specialized and up-to-date literature, I suggest a basic guide of topics, literature and materials with which to address gender in IR settings. Utilizing current and real life examples is ideal as students can relate to what they see in the news, which has the added benefit of reducing the usually high level of abstraction of the discipline. In addition, if the lecturer is willing to share his or hers research experience, even better, as these examples bestow feminist IR themes a level of familiarity that tends to resonate well with students. To sum up, the main point stressed in this article is that the lecturer should try to teach gender by utilizing classroom materials that present perspectives that lend themselves to humanizing IR and to encouraging students to identify with their subjects, a sorely needed goal in the world of 'high politics' and an interpersonal skill that should be part of the training of every IR professional.

\section{Notes}

1. Jonas Hagmman and Thomas Biersteker (2014) offer the differentiation between the published and the taught discipline. The component of the learnt discipline is my own addition to their perspective. 2. In a recent contribution, Christina Rowley and Laura J. Shepherd (2012: $149 \mathrm{ff})$ suggest that in the field of feminist security studies there have been a vast number of works that use a gendered analytical framework. In other areas, they claim, there is always at least one piece of feminist work that can be brought into the classroom. A perspective I agree with and that informs my own choice of topics and literature as detailed in the later sections of this article.

3. The journals under examination included Contexto Internacional (International Context), Revista Brasileira de Política Internacional (Brazilian Journal of International Politics), and Sociologia e Política (Sociology and Politics). The later also carries articles from other fields of the social sciences. 4. Utilizing the scielo search engine, which is Brazil's most reputable bibliographic database, I looked up the words feminism, women and gender both in English and in Portuguese - gênero; mulheres; and feminismo - respectively. It returned zero results in RBPI, one in Contexto, and in Sociologia e Política only three specifically connected to international relations.

5. If bringing in the category 'women' is still problematic, introducing subaltern women is even more challenging. Indeed, women from postcolonial countries are still seen 'at the margins' and the discipline still has not made enough room to account for different kinds of agency (see Dingli 2015) that may differ from a western liberal interpretation of rights. In this sense, IR would benefit greatly from an engagement with the area studies field of Middle East Gender where the idea that 'women' is not a monolithic category is well established. Within Gulf Arab studies, a subset of Middle Eastern studies, the investigation of the lives and achievements of so-called 'women achievers' or 'women leaders' - focused on highly educated, professional women - has been an emerging and important field. Bringing this specific category into the study of IR would aid in including Arab women as empowered agents within IR, which would make visible not only different kinds of agency, but also aid in bypassing the widespread image of Arab female oppression that still informs much of IR practice.

6. Rowley \& Shepherd (2012: 149) speak of similar concerns in the UK.

7. In this sense, Carol Cohn's (1987) article on 
the sexualized and masculinized world of nuclear deterrence still holds true.

8. The withdrawal of emotion from IR research, the favouring of a positivist epistemology as well as the idea that 'distance' between the researcher and the research subject is absolutely essential for the production of knowledge (see, e.g., Smith 2004) has already been criticized from a variety of perspectives. Nevertheless, in what concerns feminist research, Megan McKenzie (2011: 691-692) goes as far as to suggest that writing emotion 'out of our research was unrealistic, explicitly anti-feminist, and ultimately resulted in dishonest and fragmented research outputs'.

9. In this regard, Deborah Stienstra (2000: 241) gives the example of female genital mutilation. She states: "When FGM has been included in IR courses without addressing the complexities of gender, we see the perpetuation of overgeneralizations (...). At times we may assert that it is an Islamic phenomenon, a harmful practice quite different from other traditional practices found in the North, or something those in the North are better equipped to eliminate. These all suggest that the perspectives of many in the North get set up as "truth" or fact, and those perspectives from the South or from those in the North who challenge this are in error, undervalued, or ignored". Even though the experiences that I am reporting originate from a 'southern' classroom, I can very well imagine that the latter would also see itself as 'the north' as regards practices such as FGM.

10. The four additional requirements are the following: 1) guarantee of basic rights (i.e. life, dignity, and property; freedom of travel, commerce, and religion), especially those of foreign nationals; 2 ) the existence of an organized political bureaucracy with some efficiency in running the state machinery; 3 ) adherence to generally accepted international law and maintenance of a domestic system of courts, codes, and published laws that guarantee legal justice; 4) fulfilling the obligations of the international system by maintaining adequate and permanent avenues for diplomatic interchange and communication.

11. See Webb et al. (2004) for a discussion of limitations in applying feminist methods to undergraduate classes.

12. It is a perspective focused on the conditions and consequences of 'speaking security' developed by the Copenhagen School. It explains how an issue is shifted from the 'normal' political arena into the realm of emergency politics by presenting it as an existential threat. I utilize Lene Hansen's The Little Mermaid's Silent Security Dilemma (2001) to illustrate how an extremely popular IR theory fails to account for gender within its overall analytical structuring. Using the honour killings in Pakistan as examples, the author shows the specifically democratic and male-centered assumptions that underlie the supposedly universal structure of the theory.

13. Within the 1979 Islamic revolution, the new government sought to abrogate all advancements in women's rights that were made under the Shah, as they were considered un-Islamic.

14. The benefits of utilizing visual aids in the teaching of IR have been extensively discussed on active learning literature (see, e.g., Inoue \& Krain 2014; Morgan 2003).

15. See Freej's website:

http://www.freej.ae/en/Default.aspx

\section{REFERENCES}

- Abu-Lughod, Lila (2002): Do Muslim Women really need saving? Anthropological Reflections on Cultural Relativism and Its Others, in: American Anthropologist 2002/104/3.

- Al-Otaiba, Youssef (2010): Interview with Jeffrey Goldberg, Aspen Ideas Festival, 6 July 2010, available online at www.aspenideas.org

- Alloula, Malek (1986): The Colonial Harem. University of Minnesota Press: Minneapolis, London.

- Because our cause is just (2013): Documentary. Deb Bergeron (Director). Women's Learning Partnership/Rainlake Productions, Bethesda. . Cohn, Carol (1987). Sex and Death in the Rational World of Defense Intellectuals, in: Signs, $1987 / 12 / 4$.

. Cooke, Miriam (2000): Women, Religion, and the Postcolonial Arab World, in: Cultural Critique, 2000/45.

- Daily Mail (2011): The women who have to sleep with their husbands' brothers: Shortage of girls forces families into wife-sharing, Daily Mail, 28 October 2011, available online at www.dailymail.co.uk/news/article-2054420/Wife-sharingbrothers-haunts-Indian-villages-number-girls-decline.html\#ixzz3h7SX01PS

- Dingli, Sophia (2015): We need to talk about silence: Re-examining silence in International Relations theory, in: European Journal of International Relations, 2015/first published on April 8.

- Gerrit W. Gong (2002): Standards of Civilization Today, in: Mehdi Mozaffari (ed.), Globalization and Civilizations. Routledge, New York. 
- Hagmman, Jonas \& Biersteker, Thomas J. (2014): Beyond the published discipline: Toward a critical pedagogy of international studies, in: European Journal of International Relations, $2014 / 20 / 2$.

- Hansen, Lene (2000): The Little Mermaid's Silent Security Dilemma and the Absence of Gender in the Copenhagen School, in: Millennium: Journal of International Studies, 2000/29/2. - Inoue, Cristina Y.A. \& Krain, Matthew (2014): One World, Two Classrooms, Thirteen Days: Film as an Active-Teaching and Learning Tool in CrossNational Perspective, in: Journal of Political Science Education, 2014/10.

- Lee, Janet (1993): Teaching Gender politics, in: Teaching Sociology, 1993/21.

- MacKenzie, Megan H. (2011): The Forum: Their Personal is Political, Not Mine: Feminism and Emotion, in: International Studies Review, $2011 / 13 / 4$.

- Mehdi Mozaffari (2001): The Transformationalist Perspective and the Rise of a Global Standard of Civilization, in: International Relations of the Asia-Pacific, 2001/1/2.

- Mir-Hosseini, Ziba (2002): The ConservativeReformist Conflict Over Women's Rights in Iran, in: International Journal of Politics, Culture and Society, 2002/16/1

- Morgan, A. L. (2003). Toward a Global Theory of Mind: The Potential Benefits of Presenting a Range of IR Theories through Active Learning, in: International Studies Perspectives, 2003/4.

. O Globo (2013): Dilma a investidores em Nova York: Brasil é civilizado e respeita contratos (Dilma to investors in New York: Brazil is civilized and respects contracts), $O$ Globo, 25.09.2013, available online at

http://oglobo.globo.com/economia/dilma-investidores-em- nova-york-brasil-civilizado-respeitacontratos-10144417

- Oestreich, Joel E. (2007): Teaching Gender and International Relations, in: International Studies Perspectives, 2007/8.

- Rowley, Christina \& Shepherd, Laura J. (2012): Contemporary Politics: Using the 'F' Word and Teaching Gender in International Relations, in: Cathy Gormley-Heenan and Simon Lightfoot (eds.): Teaching Politics and International Relations. Palgrave, New York.
. Shrewsbury, Carolyn M. (1993). What is Feminist Pedagogy?, in: Women's Studies Quarterly, $1993 / 1 \& 2$

- Sjoberg, Laura (2007): Gender and Personal Pedagogy: Some Observations, in: International Studies Perspectives, $2007 / 8$.

- Sjoberg, Laura (2008): Gender, Justice, and the Wars in Iraq: A Feminist Reformulation of Just War theory. Lexington Books, Oxford.

- Smith, Steve (2004): Singing our World into Existence: International Relations Theory and September 11, in: International Studies Quarterly, $2004 / 48$.

- Stienstra, Deborah (2000): Cutting to Gender: Teaching Gender in International Relations, in: International Studies Perspectives, 2000/1.

- Sylvester, Christine (1994): Empathetic Cooperation: A Feminist Method for IR, in: Millennium: Journal of International Studies, 1994/23/2.

- Sylvester, Christine (2013): Experiencing the end and afterlives of International Relations/theory, in: European Journal of International Relations, $2013 / 19 / 3$.

- Tickner, Arlene B. (2009): Latin America: still policy dependent after all these years?, in: Arlene B. Tickner \& Ole Wrver (eds.): International Relations Scholarship Around the World. Wordling beyond the West. Routledge, London and New York. - Tickner, J. Ann (2005): What is your research program? Some Feminist answers to International Relations Methodological Questions, in: International Studies Quarterly, 2005/49.

- Time (2014): It's Not Just Putin: Russia's Obsession With Crimea Is Centuries-Old, Time, 19.03.2014, available online at

http://time.com/29651/putin-crimea-russia-annexation/

- Towns, Ann (2007): The Status of Women and the Ordering of Human Societies along the Stages of Civilization, in: Martin Hall \& Patrick Thaddeus Jackson (eds.): Civilizational Identity: The Production and Reproduction of "Civilizations" in International Relations. Palgrave, Basingstoke. - True, Jacqui (2005): Feminism, in: Alex J. Bellamy (ed.): International Society and its Critics. Oxford University Press, Oxford.

- Webb et al.: (2004) Feminist pedagogy in the teaching of research methods, in: International Journal of Social Research Methodology, 2004/7/5. 